\title{
Egg surface structure of the freshwater toadfish Thalassophryne amazonica (Teleostei: Batrachoididae) with information on its distribution and natural habitat
}

\author{
Ralf Britz ${ }^{1}$ and Mônica Toledo-Piza²
}

The egg surface structure of Thalassophryne amazonica, a freshwater toadfish from the Amazon basin is described. Eggs of this species show a remarkable, highly unusual system of parallel ridges and intermittent grooves that originate at the equator of the egg and lead to the micropylar pit, at which they end in a spiralling pattern. A similar egg surface structure has so far been described only from a group of Asian anabantoid percomorphs, obviously not closely related to Thalassophryne. This egg surface pattern may enhance fertilization success by guiding sperm to the micropyle. We review museum records for $T$. amazonica, present an updated map of its occurrence in the Amazon basin, and provide information on its habitat.

A estrutura da superfície do ovo de Thalassophryne amazonica um batracoidídeo de água doce da bacia amazônica é descrita. Os ovos dessa espécie apresentam um sistema notável e incomum de cristas paralelas e canais intermitentes, que se originam na porção equatorial do ovo e vão até a micrópila onde terminam em um padrão espiralado. Uma estrutura superficial de ovo semelhante foi até agora descrita apenas para um grupo de anabantóideos asiáticos, obviamente não relacionado a Thalassophryne. Esse padrão de superfície de ovo talvez aumente o sucesso da fertilização ao guiar o espermatozóide até à micrópila. Nós revisamos os registros de T. amazonica em museus, apresentamos um mapa atualizado de sua ocorrência na bacia Amazônica e fornecemos informações sobre seu habitat.

Key words: Egg attachment, Fish reproduction, Micropylar apparatus, Upper Amazon, Zona radiata.

\section{Introduction}

Toadfishes of the family Batrachoididae are a group of about 80 bottom dwelling, predominantly marine species of bony fishes. Their phylogenetic interrelationships are not entirely clear. Morphological characters appear to link them to the Lophiiformes (Patterson \& Rosen, 1989), but authors of recent molecular analyses claim a closer affinity with Synbranchiformes (Miya et al., 2005).

Some toadfishes, like the oyster toadfish Opsanus tau, are well known for their ability to produce audible sounds with sonic muscles attached to their swimbladder when disturbed or during courtship (see Fish \& Mowbray, 1970). Toadfishes also have highly developed parental care, in which the male guards the nest of eggs and the hatchlings for several weeks until they are free swimming (Arora, 1948; Dovel, 1960).

While almost all batrachoidid species inhabit marine or brackish waters, five live in freshwaters (Collette, 1966, 1973, 1995; Collette \& Russo, 1981; Silfvergrip, 1990) and at least one, Thalassophryne amazonica Steindachner 1876, inhabits tributaries of the Amazon River that are hundreds or thousands of kilometers from the sea (Collette, 1966). Up until Collette's (1966) study, this freshwater toadfish was only poorly known because the type specimens have been lost. Collette (1966) provided a redescription and illustration of $T$. amazonica based on specimens from the río Itaya in Peru and río Conambo and río Corrientes in Ecuador, all tributaries of the upper Amazon.

Along with the five species of the genus Daector, the six species of Thalassophryne belong to the batrachoidid subfamily Thalassophryninae, which is characterized by one of the most highly developed venom apparatuses in the fish world (Collette, 1966). Venom glands are associated with the hollow spines of the dorsal fin and the hollow opercular spine. They can inflict extremely painful wounds to humans, which are accompanied by dizziness, fever, and even necrosis of tissue close to the area where the spine penetrated the skin (Haddad Junior et al., 2003).

\footnotetext{
${ }^{1}$ The Natural History Museum, Department of Zoology. Cromwell Road London, SW7 5BD, United Kingdom. r.britz@nhm.ac.uk ${ }^{2}$ Universidade de São Paulo, Departamento de Zoologia, Instituto de Biociências. Rua do Matão, travessa 14 n 101 , 05508-090 São Paulo, SP, Brazil. mtpiza@usp.br
} 
There is no information available on the biology of $T$. amazonica, although this species has been exported now and then as an aquarium fish since the 1990s. We used the repeated spawning activities in captivity of a group of $T$. amazonica to study its egg morphology in detail and provide a description of its unusual egg surface structure.

\section{Material and Methods}

Six mature individuals of T. amazonica were purchased from a wholesaler in Germany and kept in the aquarium facilities of the Natural History Museum in London. They were kept in a tank with the dimensions $80 \mathrm{~cm} \times 40 \mathrm{~cm} \times 40 \mathrm{~cm}$, with tap water, $\mathrm{pH} 8.5$ and conductivity of $850 \mu$ Siemens. The bottom consisted of a $5 \mathrm{~cm}$ high layer of fine sand. The fish spent all their time buried in the sand. They accepted only live food and were fed once a week with live river shrimps (Palaemon spp.). Egg deposition occurred a few days after a 50 per cent water change with deionised water (50-100 $\mu \mathrm{S})$ and was most likely triggerd by the decrease in conductivity. Eggs were found on the surface of the sandy substrate on which they sat with their adhesive foot. Eggs were removed from the tank and fixed in either formalin or glutaraldehyde and subsequently dehydrated in a graded series of ethanol: 15, 30, 50, 70, 80, 90, 95, and100\%. Eggs were then critical point dried with liquid $\mathrm{CO} 2$ in a critical point apparatus, mounted on aluminium stubs, sputter coated with gold and observed and photographed in a ZEISS DSM 940 scanning electron microscope.

We also made a brief survey of specimens of Thalassophryne amazonica that are deposited in collections known to have large number of Amazonian species, in order to provide information on the current distribution of this species. Museum acronyms are as follows: INPA (Instituto Nacional de Pesquisas da Amazônia, Manaus); MPEG (Museu Paraense Emílio Goeldi, Belém), and MZUSP (Museu de Zoologia da Universidade de São Paulo, São Paulo).

\section{Results}

\section{Egg structure}

On three occasions eggs were found in the tank with the six Thalassophryne: 22 eggs on 4 Dec 2008, 16 eggs on 1 Oct 2010, and 21 eggs on 26 Oct 2010. Spawned eggs of Thalassophryne amazonica are large and the yolk is amber coloured (Fig. 1). They measure up to $5.6 \mathrm{~mm}$ at the equator and up to $4.2 \mathrm{~mm}$ from pole to pole. They have a whitish translucent foot with which they rest on the sandy bottom. Under the stereomicroscope the animal egg pole opposite the foot shows a surface structure of folds or ridges that lead towards the micropyle.

Scanning electron microscopy reveals additional details (Fig. 2). The spiralling surface pattern on the $7 \mu \mathrm{m}$ thick zona radiata starts at the equator of the egg and consists of obliquely running ridges and intermittent grooves that extend towards the animal egg pole. At the animal pole these ridges and grooves converge towards the micropylar region. Here they end in a counter-clockwise spiral. The deep micropylar pit sits at the top of a slightly elevated crater-like area at the animal egg pole. The $5 \mu \mathrm{m}$ wide micropyle is located in the middle of the $20 \mu \mathrm{m}$ wide micropylar pit. The foot of the egg consists of a homogenous matrix and a number of sand grains are attached to it.

\section{Distribution and habitat}

In addition to the localities listed in Collette (1966), Thalassophryne amazonica has since been collected from the following localities (see map in Fig. 3): INPA 37635, 1, ESEC Juami-Japurá, rio Juami, AM, at beach, 2 8’5”S 68¹9’W, 5 Aug 2005, F. Mendonça and crew. MPEG 12527, 7, Igarapé do Onça, Municipality of Coari, AM, 452'8”S 65¹8'4”W, Nov 2006. MPEG 17776, 1, Igarapé do Onça, Municipality of Coari, AM, 452'9.7’'S 65¹8'2.8’W, Aug 2007. MZUSP 30324, 1, rio Tefé, Jurupari, AM, 3²2’S 6444’18’W, 1 Aug 1979, M. Goulding. MZUSP 31402, 1, rio Tefé, Vista Escura AM, 3²2’S 6444’18’W, 4 Aug 1979, M. Goulding.

Specimens from the Peruvian Amazon were collected by Hans-Georg Evers but were not preserved (see Fig. 4 for habitat): río Itaya, along the road between Iquitos and Nauta, km 40, Puente Tocon, 44'5”S 73²6’2’W, 18 Sep 2005 and 03 May/2008; río Momon 340’2”S 737’1”W.

For three localities we have also water parameters: in the río Itaya near Iquitos, the species was found in acidic water with a $\mathrm{pH}$ of 5.5 to 6 , a very low conductivity of 14 to $89 \mu \mathrm{S}$ and a temperature of 25.8 to $30.4^{\circ} \mathrm{C}$. The bottom was mud and the water turbid. The locality in the río Momon also had similar water parameters. The rio Juami, showed again similar parameters, $\mathrm{pH}$ 5.38, an extremely low conductivity of only $6.6 \mu \mathrm{S}$, a temperature of $27.1^{\circ} \mathrm{C}$, and an $\mathrm{O} 2$ content of $6.92 \mathrm{mg} /$ 1. The bottom was a mixture of sand and mud typical of enclosed beaches with slow flowing waters. The only water parameter we have for Igarapé do Onça is pH 6.4 to 7.8, slightly higher than in the localities listed previously. The igarapé was 20 to $80 \mathrm{~cm}$ deep and $12 \mathrm{~m}$ wide with a sandy bottom.

\section{Discussion}

The little published information on the early life history of batrachoidids was recently summarized by Collette (2006). The most detailed information on reproduction and early development is available for Opsanus tau through the work of Dovel (1960). The relatively few eggs (ca. 100) are around $5 \mathrm{~mm}$ and are attached to the undersides of objects with the aid of an adhesive disc at the vegetal egg pole. The newly hatched larvae measure already $7.4 \mathrm{~mm}$ and sit on a very large yolk sac the bottom of which is still attached to the inside of the remnants of the egg shell via a large attachment organ at its tip. The larvae remain attached until the yolk sac is resorbed and leave the nesting site as small juveniles with fully formed fins at 18 mm standard length. Eggs and attached larvae are guarded and fanned by the male. The development of Porichthys notatus (Arora, 1948) resembles that of Opsanus in all important details and may indicate that this is the primitive condition for at least 

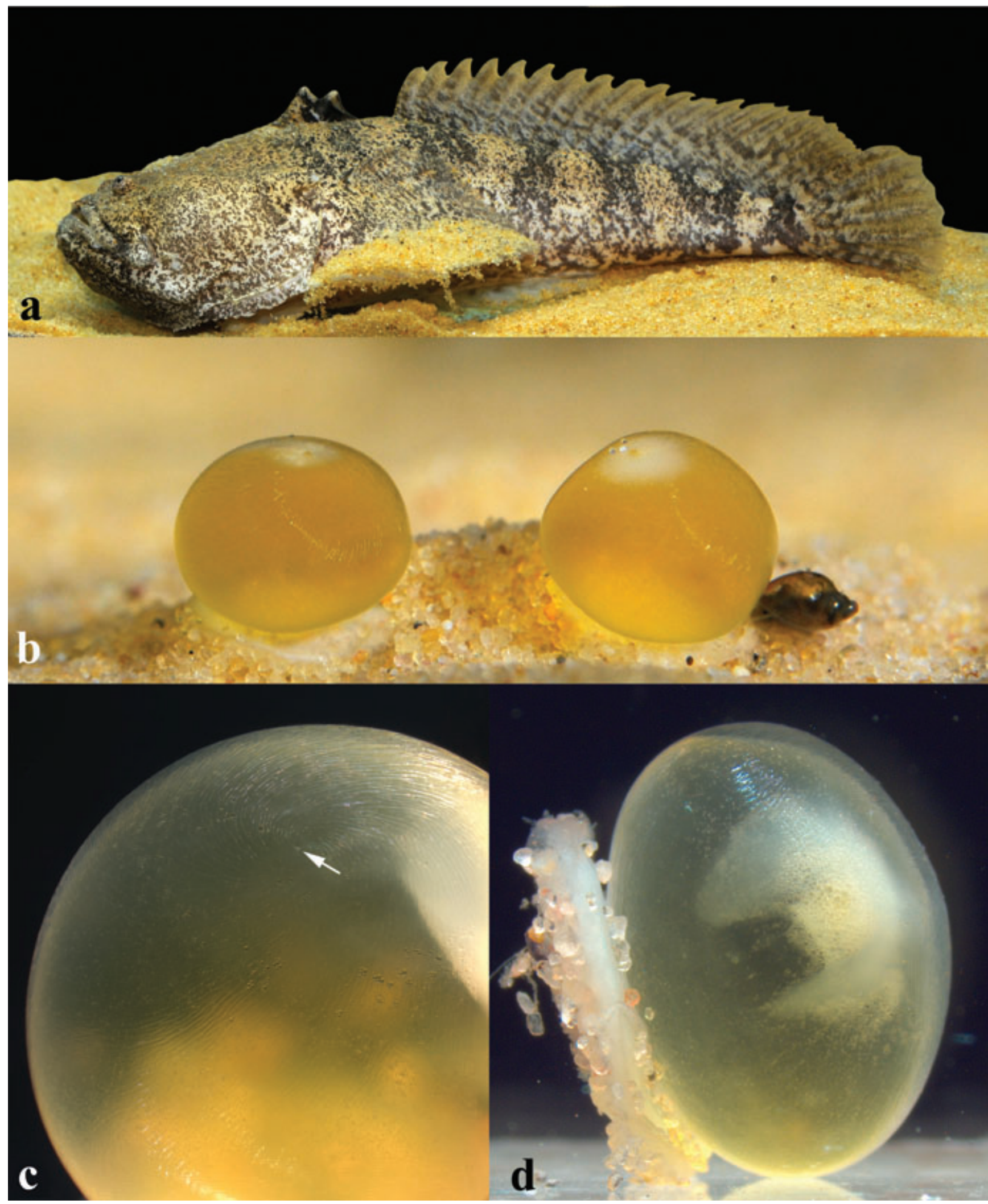

Fig. 1. a, An adult individual of Thalassophryne amazonica. Note the two erected dorsal fin spines, the large pectoral fins, and the confluence of dorsal and caudal fins.b - d, spawned eggs of T. amazonica. Eggs are ellipsoid and relatively large with a large amount of yolk. They sit on top of the sand with the aid of their whitish adhesive foot. Note spiralling pattern clearly visible at 40-times magnification with light microscopy. Arrow in c points to micropyle. 


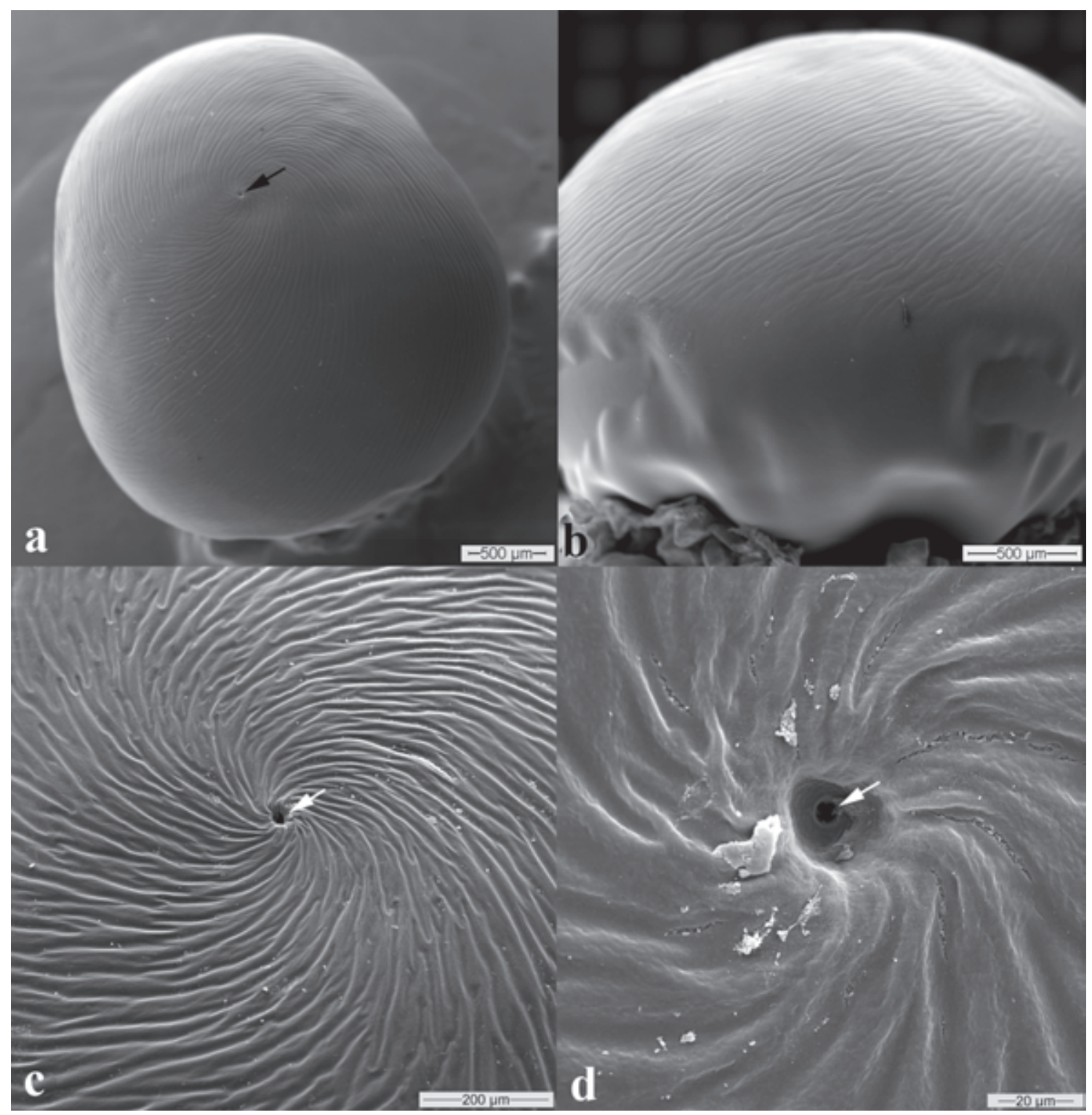

Fig. 2. Scanning electron micrographs of eggs of Thalassophryne amazonica. a, View on animal egg pole showing ridges and intermittent grooves forming a spiralling pattern towards the micropyle (marked by arrow). $\mathbf{b}$, sideview of the equatorial region of the egg illustrating the start of the ridge and groove system at the widest part of the egg, the smooth surface area towards the vegetal egg pole and the adhesive foot. c, micropylar area with spiralling ridges and grooves, micropylar pit marked by arrow. d, deep micropylar pit with micropylar opening (marked by arrow) at its bottom.

the two batrachoidid subfamilies Batrachoidinae and Porichthyinae. No information has been published for any members of the third subfamily Thalassophryninae. From our observations of captive Thalassophryne amazonica it seems that the reproductive behaviour of this species differs in several ways from that of Opsanus and Porichthys. Egss were not attached to any substrate but sat on top of the sand with the aid of their adhesive foot. There appeared to be no parental care, as the eggs were not fanned or guarded. We cannot, however, exclude the possibility that the eggs we discovered in the aquarium were not spawned and fertilised, but actually released by the female accidentally after the major water changes we performed.

The most remarkable feature of $T$. amazonica eggs is their surface pattern of parallel obliquely running ridges and grooves that end in a counter-clockwise spiral close to the micropyle. Ridged egg surfaces have been reported from few teleosts including, for example, the loricariid catfish Sturisoma aureum (Riehl \& Patzner, 1991) the cyprinid Puntius conchonius (Amanze \& Iyengar, 1990) and the characiform Astyanax bimaculatus (Rizzo et al., 2002). A spiralling pattern of ridges that run towards the micropylar area, however, is so 


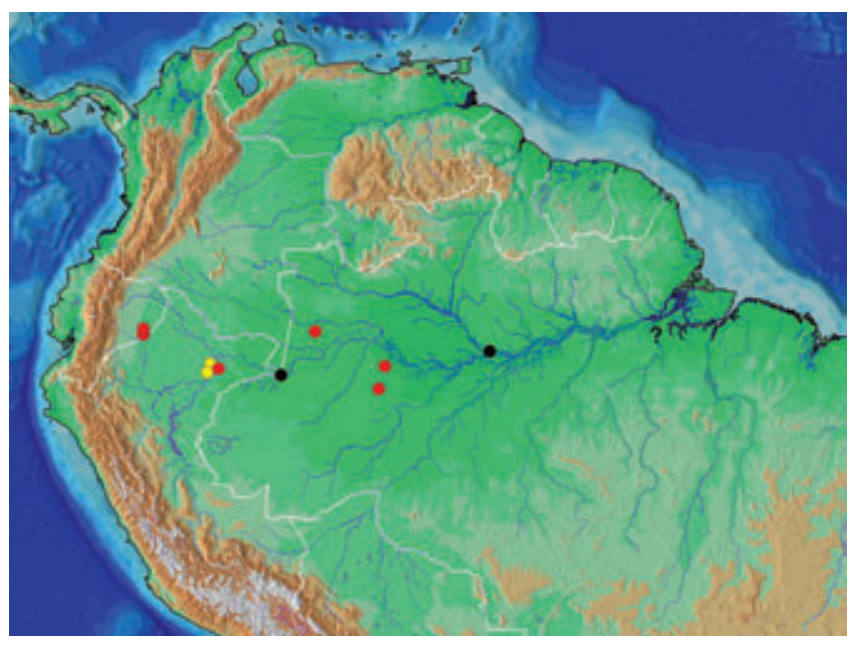

Fig. 3. Map of the northern portion of South America showing the distribution of Thalassophryne amazonica based on records we surveyed. Red dots indicate localities for which there is material deposited in collections; yellow dots indicate localities for which no specimens were deposited in collections. Black dots indicate type localities. The "?” indicates a possibly incorrect record for the species by Steindachner (see text for discussion).

far only known from the anabantoid Luciocephalus (Riehl \& Kokoscha, 1993; Britz et al., 1995) and its closest relatives Sphaerichthys, Parasphaerichthys, and Ctenops (Britz et al., 1995; Britz \& Kottelat, 2002) and is now reported for $T$. amazonica. This spiralling system of ridges was hypothesized to increase success of fertilization and this may also apply to the spiralling pattern in T. amazonica eggs.

The adhesive foot of Thalassophryne eggs is also quite unusual among bony fishes with adhesive eggs, in that their adhesion is not the result of a system of filaments but of a homogenous substance. Adhesive egg filaments are quite widespread among teleosts and have been reported from gobies (Giulianini et al., 1994), blennies (Patzner, 1984), gobiesocids (Breining \& Britz, 2000), chaudhuriid synbranchiforms (Kerle et al., 2000), different percoids (Mooi, 1990; Mooi et al., 1990; Britz, 1997), cichlids (Stiassny \& Mezey, 1993) and are one of the defining synapomorphies of atherinomorphs (Rosen \& Parenti, 1981; Collette et al., 1983; White et al., 1983; Able, 1983). An adhesive foot consisting of a homogeneous substance is not very common and at least to our knowledge has so far been described only for Indostomus paradoxus (Britz, 2000), a member of the gasterosteiforms (Britz \& Johnson, 2002). Clearly more information on the egg strcture and other early life history characters of other batrachoidids and related taxa are needed to better evaluate the distribution and significance of the characters we report here for $T$. amazonica.

Thalassophryne amazonica is apparently a rare species known from relatively few specimens in collections, and it
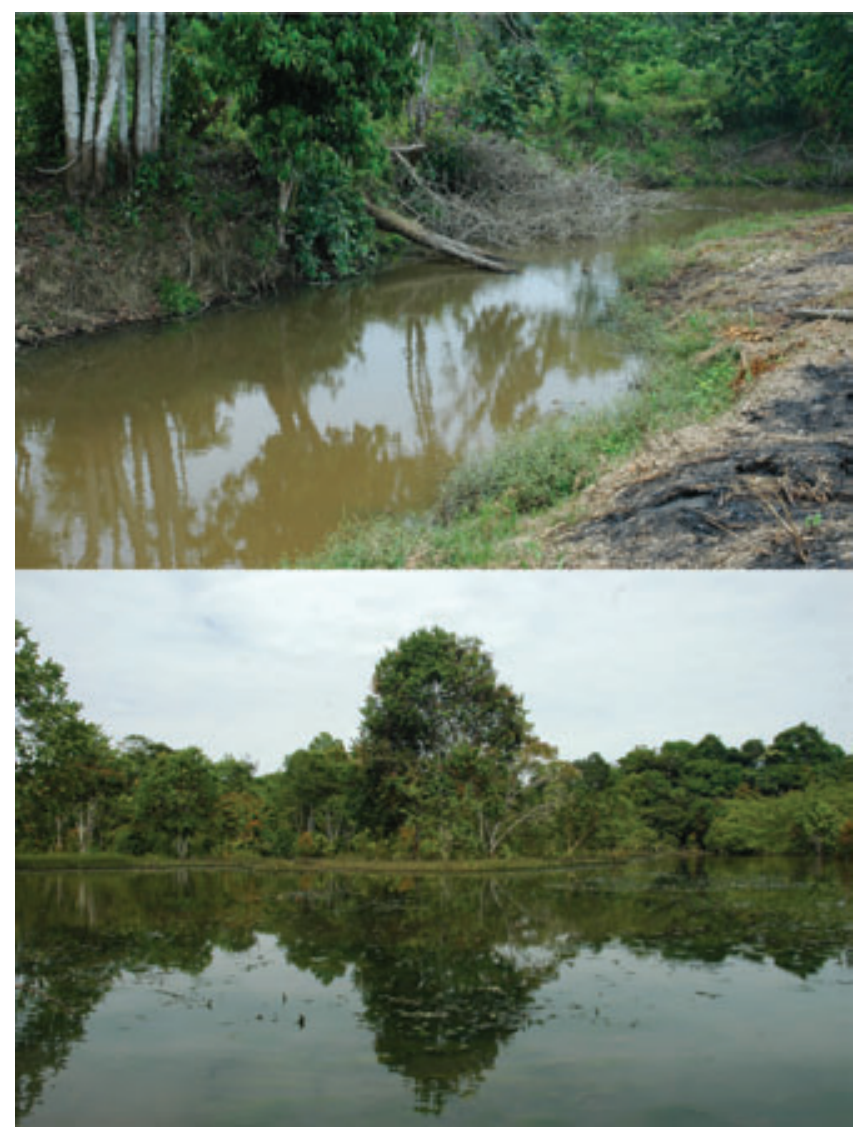

Fig. 4. Habitat of Thalassophryne amazonica in two localities of the Peruvian Amazon where the species was collected. a. Río Itaya, along the road between Iquitos and Nauta, $\mathrm{km} 40$, Puente Tocon (44’5"S 73²6’23"W); b. Río Momon (340’23"S $\left.73^{\circ} 17^{\prime} 14^{\prime \prime}\right)$.

seems to be restricted to drainages from the middle and upper Amazon region. A preliminary survey of specimens from institutions that house large collections of Amazonian fish species (INPA, MPEG, and MZUSP), resulted in the record of 5 lots all collected in tributaries of the Rio Amazonas above Manaus (Fig. 3).

It is clear from the water parameters reported to us that Thalassophryne amazonica prefers acidic waters with low conductivity and a higher temperature. The fish were found on a muddy or sandy bottom, in which they can supposedly bury themselves easily. A search for this type of habitat may help to locate this rare species also in additional streams of the upper Amazon.

In the original description of the species, Steindachner (1876:115) stated: "Thalassophryine amazonica scheint eine echte Süsswasser-Fischart zu sein, denn man kennt sie bisher nur von der Mündung des Rio negro und aus dem Amazonenstrome unterhalb Tabatinga (durch Natterer und Wesse1) sowie aus dem Xingu." ("T. amazonica seems to be a true freshwater species, because it is only known from the mouth of the Rio Negro and from the Amazon river below 
Tabatinga (by Natterer and Wessel), as well as from the Xingu”, our translation)

He thus reported it to be known from the mouth of the Rio Negro, from Tabatinga, and from the Rio Xingu. The first two localities are placed within the range of the species estimated from material deposited in the above mentioned collections, however we did not find specimens of Thalassophryne amazonica from the Rio Xingu. Unfortunately, the type specimens of this species could not be located (pers. comm. H. Wellendorf, 20 Jun 2012)

We checked Steindachner's paper and found that Rio Xingu is mentioned four times, three of these in connection with the Thayer-expedition. The only time that there is no mention of the Thayer-expedition is in connection with $T$. amazonica. Natterer, a naturalist who travelled Brazil, and Wessel, a seller of natural history specimen, are mentioned on numerous occasions in Steindachner's paper in connection with specimens from the mouth of the Rio Negro (Natterer) and Tabatinga (Wessel) respectively. It thus seems reasonable to assume that Steindachner had also at least two specimens available by these two individuals for his description of $T$. amazonica. There are no Xingu Thalassophryne specimens from the Thayer expedition in the collection on the Museum of Comparative Zoology (MCZ). However, there are two specimens of $T$. nattereri, a species Steindachner also described in the same paper, from the Thayer-expedition that were collected in Para. Based on our short review it appears most plausible to us that the Xingu locality mentioned by Steindachner was not based on specimens. We know of no $T$. amazonica specimen from the Xingu and all recent collections of this species are from the middle and upper Amazon exclusively (see Fig. 3 and Collette, 1966, 2003).

\section{Acknowledgements}

For providing information on Thalassophryne amazonica (museum records, locality information, water parameters) we are grateful to Osvaldo Oyakawa (MZUSP); Marcelo Rocha and Jansen Zuanon, (INPA) Fernando Mendonça, Luciano Montag (UFPA), and Hans-Georg Evers. We thank Enio Mattos and especially Phillip Lenktatis (IBUSP) for the careful preparation of the Thalassophryne amazonica eggs for examination and for taking the digital images of the eggs with the SEM. The map was prepared with the help of a tutorial provided by (http:// wikipeixes.com.br) MTP acknowledges partial funding by CNPq (307067/2010-6).

\section{Literature Cited}

Able, K. W. 1983. Cyprinodontiformes: Development and relationships. Pp. 362-368. In: Moser, H. G., W. J. Richards, D. M. Cohen, M. P. Fahay, A. W. Kendall Jr. \& S. L. Richardson (Eds.). Ontogeny and Systematics of Fishes. Special Publication Number 1, American Society of Ichthyologists and Herpetologists, Lawrence, Allen Press, 760p.
Amanze, D. \& A. Iyengar. 1990. The micropyle: a sperm guidance system in teleost fertilization. Development, 109: 495-500.

Arora, H. L. 1948. Observations on the habits and early life history of the batrachoid fish, Porichthys notatus Girard. Copeia, 1948: 89-93.

Breining, T. \& R. Britz . 2000. Egg surface structure of three clingfish species, using scanning electron microscopy (Teleostei: Gobiesocidae). Journal of Fish Biology, 56: 1129-1137.

Britz, R. 1997. Egg surface structure and larval cement glands in nandid and badid fishes (Teleostei, Percomorpha), with remarks on phylogeny and zoogeography. American Museum Novitates, 3195: 1-17.

Britz, R. 2000. Aspects of the reproduction and development of Indostomus paradoxus Prashad \& Mukerji 1929 (Teleostei, Gasterosteiformes). Ichthyological Exploration of Freshwaters, 11: 305-314.

Britz, R. \& G. D. Johnson. 2002. “Paradox Lost”: Skeletal ontogeny of Indostomus paradoxus and its significance for the phylogenetic relationships of Indostomidae (Teleostei, Gasterosteiformes). American Museum Novitates, 3383, 1-43.

Britz, R. \& M. Kottelat. 2002. Parasphaerichthys lineatus, a new species of labyrinth fish from southern Myanmar (Teleostei: Osphronemidae). Ichthyological Exploration of Freshwaters, 13: 243-250.

Britz, R., M. Kokoscha, \& R. Riehl. 1995. The anabantoid genera Ctenops, Luciocephalus, Parasphaerichthys and Sphaerichthys as a monophyletic group: evidence from egg surface structure and reproductive behaviour. Japanese Journal of Ichthyology, 42: $71-79$.

Collette, B. B. 1966. A review of the venomous toadfishes, subfamily Thalassophryninae. Copeia, 1966: 846-864.

Collette, B. B. 1973. Daector quadrizonatus, a valid species of freshwater venomous toadfish from the Rio Truando, Colombia, with notes on additional material of other species of Daector. Copeia, 1973: 355-357.

Collette, B. B. 1995. Potamobatrachus trispinosus, a new freshwater toadfish (Batrachoididae) from the Rio Tocantins, Brazil. Ichthyogical Exploration of Freshwaters, 6: 333-336.

Collette, B. B. 2006. Family Batrachoididae (toadfishes). Pp. 509510. In: Reis, R. E., Kullander, S. O. \& C. J. Ferraris. Check List of the freshwater fishes of South and Central America. EDIPUCRS, Porto Alegre, 729p.

Collette, B. B. \& J.L. Russo. 1981. A revision of the scaly toadfishes, genus Batrachoides, with descriptions of two new species from the eastern Pacific. Bulletin of Marine Science, 31: 197-233.

Collette, B. B., G. E. McGowan, N. V. Parin \& S. Mito. 1983. Beloniformes: Development and relationships. Pp. 335-354. In: Moser, H. G., W. J. Richards, D. M. Cohen, M. P. Fahay, A. W. Kendall jr \& S. L. Richardson (Eds.). Ontogeny and Systematics of Fishes. Special Publication Number 1, American Society of Ichthyologists and Herpetologists, Lawrence, Allen Press, 760p.

Dovel, W. 1960. Larval development of the Oyster Toadfish, Opsanus tau. Chesapeake Science, 1960: 187-195.

Fish, M. P. \& W. H. Mowbray. 1970. Sounds of Western North Atlantic Fishes. Baltimore: Johns Hopkins, 205p.

Giulianini, P. G., di Marcotullio, A., Ferrero, E. A. \& R. A. Patzner. 1994. Light microscopical and ultrastructural cytology of the ovaries in the sea-grass goby Zosterisessor ophiocephalus (Osteichtyes, Gobiidae). Bolletino de Zoologia, 61: 135-144

Haddad Junior, V., Pardal, P. P. O., Cardoso, J. L. C., \& I. A. Martins. 2003. The venomous toadfish Thalassophryne nattereri (Niquim or Miquim): report of 43 injuries provoked in fishermen of 
Salinópolis (Pará State) and Aracaju (Sergipe State), Brazil. Revista do Instituto de Medicina Tropical de São Paulo, 45: 221-223.

Kerle, R., R. Britz \& P. K. L. Ng. 2000. Habitat preference, reproduction and diet of the earthworm eel, Chendol keelini (Teleostei: Chaudhuriidae). Environmental Biology of Fishes, 57: 413-422.

Miya, M., T. P. Satoh \& M. Nishida, 2005. The phylogenetic position of toadfishes (order Batrachoidiformes) in the higher ray-finned fish as inferred from partitioned Bayesian analysis of 102 whole mitochondrial genome sequences. Biological Journal of the Linnean Society, 85: 289-306.

Mooi, R. 1990. Egg surface morphology of pseudochromoids (Perciformes: Percoidei), with comments on its phylogenetic implications. Copeia, 1990: 455-475.

Mooi, R. D., Winterbottom, R. \& M. Burridge. 1990. Egg surface morphology, development, and evolution in the Congrogadinae (Pisces: Perciformes: Pseudochromidae). Canadian Journal of Zoology, 68: 923-934.

Patterson, C. \& D. A. Rosen. 1989. The Paracanthopterygii revisited: order and disorder. in Cohen, D. M. (ed.) Papers on gadiform fishes. Natural History Museum Los Angeles County, Science Series, 32: 5-36.

Patzner, R. 1984. The reproduction of Blennius pavo (Teleostei, Blenniidae). II. Surface structure of the ripe egg. Zoologischer Anzeiger, Jena, 213: 44-50.

Riehl, R. \& M. Kokoscha. 1993. A unique egg surface pattern and micropylar apparatus in the eggs of Luciocephalus sp. (Perciformes, Luciocephalidae). Journal of Fish Biology, 43: 617-620.
Riehl, R. \& R. A. Patzner. 1991. Breeding, egg structure and larval morphology of the catfish Sturisoma aureum (Steindachner) (Teleostei, Loricariidae). Journal of Aquariculture and Aquatic Scicences, 6: 1-6.

Rizzo , E., Y. Sato, B. P. Barreto \& H. P. Godinho. 2002. Adhesiveness and surface patterns of eggs in neotropical freshwater teleosts. Journal of Fish Biology, 61: 615-632.

Rosen D. E. \& L. R. Parenti. 1981. Relationships of Oryzias and the groups of atherinomorph fishes. American Museum Novitates, 2719: 1-25.

Silfvergrip, A. M. C. 1990. Additional specimens of the venomous toadfish Daector gerringi (Teleostei: Batrachoididae), hitherto known only from the holotype. Ichthyological Exploration of Freshwaters, 1: 253-256.

Stiassny, M. L. J. \& J. G. Mezey. 1992. Egg attachment systems in the family Cichlidae (Perciformes: Labroidei), with some comments on their significance for phylogenetic studies. American Museum Novitates, 3058: 1-11.

White, B. N., R. J. Lavenberg \& G. E. McGowan. 1983. Atheriniformes: Development and relationships. Pp. 355-362. In: Moser, H. G., W. J. Richards, D. M. Cohen, M. P. Fahay, A. W. Kendall jr \& S. l. Richardson (Eds.). Ontogeny and Systematics of Fishes. Special Publication Number 1, American Society of Ichthyologists and Herpetologists, Lawrence, Allen Press, 760p.

Submitted June 28, 2012 Accepted September 10, 2012 Published September 28, 2012 